\title{
Chicken embryo as an experimental model for the study of gastroschisis ${ }^{1}$
}

\author{
O embrião de galinha como modelo experimental para o estudo da gastrosquise
}

\author{
Carlos André Tarrio Gandara ${ }^{I}$, Eduardo Spadari Araújo ${ }^{I}$, Ubirajara Índio Carvalho da Motta ${ }^{I I}$ \\ ${ }^{\text {I }}$ Pediatric Surgeon, Caxias do Sul - RS, Brazil. \\ II Full Professor, Pediatric Surgery, Federal University of Rio Grande do Sul (in Memorian), Brazil.
}

\begin{abstract}
Purpose: To reproduce the experimental model of gastroschisis in chicken embryos and to prove that the histopathological changes that occur in this model can be compared to those in human gastroschisis. Methods: A total of 278 Leghorn hen (Gallus domesticus) eggs were used. The embryos were divided into three groups: the gastroschisis group, in which the umbilical cord was opened through an orifice made in the eggshell, and the intestinal loops were exposed to a mixture of amniotic liquid and allantoid; the mixture group, in which the amniotic fluid and allantoid were simply mixed without manipulating the umbilical stump and without exposing intestinal loops; and the control group which consisted of normal embryos in which no procedure was performed. The procedures were performed on the $13^{\text {th }}$ day of embryo development and the study ended on the $19^{\text {th }}$ day, when the intestinal loops of the embryos were removed and sent for conventional histological study and digital morphometric analysis. Results: At the end of the experiment, 23 live embryos were obtained in the gastroschisis group (11.1\% survival), and 18 of these presented exposed intestinal loops ( $8.7 \%$ success). The embryos of the gastroschisis group weighed less than those of the other two groups. The gastroschisis group also developed intestinal changes consisting of the thickening of the intestinal wall, inflammatory infiltration of the serosa and mucosa, ischemic changes in the intestinal wall and formation of a fibrin layer over the loops. These findings are characteristic of human gastroschisis and were not observed in the two other groups studied. Conclusion: The experimental model in chicken embryos proved able to reproduce the intestinal changes of human gastroschisis.
\end{abstract}

Key words: Gastroschisis. Chicken Embryo. Models, Animal.

\section{RESUMO}

Objetivo: Reproduzir o modelo experimental da gastrosquise em embriões de galinha. Métodos: Foram utilizados 278 ovos de galinha da raça Leghorn (Gallus domesticus). Os embriões foram divididos em três grupos: grupo gastrosquise, no qual, através de um orifício na casca do ovo, o cordão umbilical foi aberto e as alças intestinais expostas a uma mistura de líquidos amniótico e alantóide; grupo mistura, no qual se promovia apenas a mistura de líquidos amniótico e alantóide, sem a exposição de alças intestinais; e o grupo controle, que consistia de embriões normais e nos quais nenhum procedimento foi realizado. Os procedimentos foram feitos no $13^{\circ}$ dia do desenvolvimento embrionário, e o estudo encerrado no $19^{\circ}$, quando as alças intestinais dos embriões foram removidas e encaminhadas para análise histológica convencional e análise morfométrica digital. Resultados: Ao final do experimento, foram obtidos 23 embriões vivos do grupo gastrosquise (11,1\% de sobrevida), 18 dos quais apresentavam alças intestinais expostas $(8,7 \%$ de sucesso). Os embriões do grupo gastrosquise apresentaram um peso menor que os dos outros grupos. Este grupo também desenvolveu alterações intestinais consistindo em espessamento da parede, infiltrado inflamatório da serosa e mucosa, alterações isquêmicas da parede intestinal e formação de uma camada de fibrina sobre as alças. Tais achados são característicos da gastrosquise humana e não foram observados nos demais grupos. Conclusão: O modelo experimental em embriões de galinha mostrou ser capaz de reproduzir as alterações intestinais da gastrosquise humana.

Descritores: Gastrosquise. Embrião de Galinha. Modelos Animais.

1. Research performed at the Surgery Post-graduated Program, Medical School,of the Federal University of Rio Grande do Sul and Experimental Surgery Laboratory of Caxias do Sul University, Brazil.

\section{Introduction}

Gastroschisis has evolved in the past 50 years from a fatal pathology to survival rates around $90 \%$. This is due to advances achieved in modern neonatology and neonatal surgery. However, a significant morbidity remains, mainly related to the delay in the beginning of normal intestinal functioning observed in patients. This topic is the object of study at a num- ber of centers aiming at the determination of the origin of the condition and the promotion of solutions. Experimental models in animals, such as sheep, rabbits, rats and chickens, are a key part of these studies.

A chicken embryo was used as an experimental model in Pediatric Surgery by EARLAM in $1972^{1}$, in the study of intestinal atresia. This model also appears in studies of esophageal atresia ${ }^{2}$, Hirschsprung's disease ${ }^{3}$, meconial peritonitis ${ }^{4}$, 
and meningomyelocele ${ }^{5}$. The first studies using chicken embryo as models for the study of gastroschisis appeared with TIBBOEL in Holland ${ }^{6}$ and were followed by researchers in Spain $^{7}$ and Turkey ${ }^{8}$.

The objective of this work was to reproduce, under appropriate conditions, an experimental gastroschisis model in chicken embryos.

\section{Methods}

In the study, 278 fecundated eggs from Leghorn chickens (Gallus domesticus) were used.

The eggs selected for the study were removed from the incubator on the $12^{\text {th }}$ day of embryonic development for the procedure to be carried out on the $13^{\text {th }}$ day. In the laboratory, the eggs were placed in an incubator with a heating system using circulating hot air, which was suitable to this purpose (HovaBator $^{\circledR}$ Incubator, Model G.Q.F. Mgf. Co. Savannah, Ga. USA), and kept at a temperature of $37.5^{\circ} \mathrm{C}$ in an environment with $80 \%$ humidity and were rotated manually 1 or 2 times a day before the procedure.

For data analysis, the sample was divided into 3 groups: group G (gastroschisis) - 18 embryos in which the surgical procedure was carried out to create gastroschisis on the $13^{\text {th }}$ day of embryonic development, and, at the end of the experiment, on the $19^{\text {th }}$ day, when the egg was opened the animals were alive and with the intestine protruding from the abdominal cavity; Group M (mixture of amniotic fluid and allantoid only) - 12 embryos in which the experiment was carried out on the $13^{\text {th }}$ day, and an orifice was made in the eggshell and the amniotic and allantoid membranes were opened, leading to the mixture of amniotic and allantoic fluids. This group differed from the gastroschisis group because there was no manipulation of the umbilical cord (without exposing the loops). On the $19^{\text {th }}$ day, the eggs were opened and the umbilical stump of each living animal was examined to ensure there were no exposed viscera, then it was accessed and the loops of the small intestine located at that site were removed for examination; Group C (Control): ten 19-day old embryos brought straight from the incubator, in which no procedure was carried out. The eggs were opened, and the small intestine near the umbilical ring was removed for examination.

\section{Surgical procedure to create gastroschisis}

With a mosquito forceps, an $1 \mathrm{~cm}$ orifice at the egg pole was opened. Next, the air chamber of the egg was accessed and on the floor of the air chamber was the egg membrane, which was opened in conjunction with the chorioallantoic membrane. Bleeding was controlled with the gentle grasping of the vessels with a bipolar cautery forceps. Subsequently, the amniotic cavity was accessed, and the umbilical cord was sought with the hook. This maneuver is facilitated by following the large umbilical vessels that are readily identified or by exploring, with the hook, the lower limbs of the embryo. Once identified, the umbilical cord was gently pulled out of the egg, and the structures in its interior were identified. The intestinal loops were easily visible within the umbilical cord. Using the iris scis- sors with the aid of the Adson forceps, an opening was made in the umbilical cord as close as possible to the embryo's abdomen, at the area called umbilical stump. Next, a gentle pressure was exerted to lead some intestinal loops to exit through the opening. At this time, special attention was drawn to the umbilical vessels that run within the umbilical cord; an injury in these vessels resulting in bleeding would render the procedure inviable.

After the loops were brought out, the umbilical cord was put back into the egg. The opening margin in the eggshell was cleaned of blood and amniotic fluid residues, and the orifice was closed with a plastic dressing (Tegaderm ${ }^{\mathrm{TM}}-3 \mathrm{M}$ Health Care. St. Paul, USA). Subsequently, the egg was placed back in the incubator, and the temperature and humidity were checked 3 times a day. Rotation was performed manually 1-2 times a day. At the end of the experiment, on the $19^{\text {th }}$ day, the eggs were removed from the incubator, weighed and opened for examination. The living animals were examined and classified as presenting gastroschisis or not. Those that did not present exposed intestinal loops were excluded, and the ones with the loops of the small intestine exposed were subjected to drying of the excess amniotic fluid, photographed, weighed, and euthanasia was carried out by exsanguination of the umbilical vessels. The intestine exposed through the abdominal defect was removed for later anatomopathological analysis. These embryos comprised the gastroschisis group $(\mathrm{G})$ in the study.

The intestinal loops were fixed in $10 \%$ formalin and sent to the pathology laboratory for fixation in paraffin. The intestinal sections were mounted on glass slides and stained with hematoxylin and eosin. A standard histological evaluation of the sections was performed for inflammatory signs and fibrin and collagen formation, in accordance with previously published scores ${ }^{9}$. The morphometric analyses were carried out using digitalized images obtained from optical microscopy with the Zeiss ${ }^{\mathrm{TM}}$ microscope (Axiastar Model), using smooth, achromatic lenses and phototube (Sony ${ }^{\mathrm{TM}}$ videocamera DXC 151), and analyzed by the integrated morphometry and image analysis software Image Pro Plus - Media Cybernetics ${ }^{\mathrm{TM}}$.

Through digital analysis it was possible to calculate in micrometers the thickness of the intestinal wall for each histological section.

The variables studied were: egg weight, egg length and width, embryo mortality due to the procedure, embryo weight, embryo/egg weight ratio, procedure accidents, evaluation of structures exposed by gastroschisis, evaluation of the intestinal inflammation using a semi-quantitative score, by conventional histological analysis, intestinal thickness measures verified via digital morphometric analysis of the sections, with six random measurements being taken for each embryo, and evaluation of the number of myoenteric nerve plexuses.

\section{Results}

Of the 236 eggs in the gastroschisis group (G), in 207 $(87.7 \%)$ the surgical procedure was carried out successfully, and $29(12.3 \%)$ presented accidents during the procedure.

Of the 207 embryos subjected to the creation of gastroschisis, $184(88.9 \%)$ were dead by the end of the experi- 
ment, while $23(11.1 \%)$ were alive. Therefore, the rate of survival from the procedure for the creation of gastroschisis was $11.1 \%$.

Of the 23 embryos that survived the experiment, 5 $(21.7 \%)$ presented scar tissue formation in the abdominal defect without exposed intestinal loops, and 18 presented gastroschisis, identified by examination of the embryo (Figure 1).

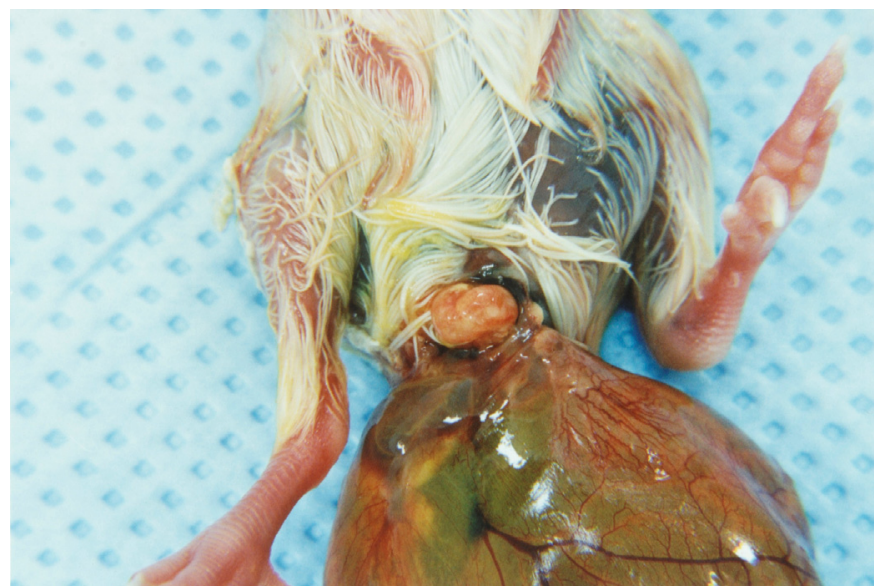

FIGURE 1 - Embryo from the gastroschisis group. Exposed intestinal loops, laterally to the umbilical cord and yolk sac. Note the hyperemia and the inflammatory aspect of the loops

Thus, considering the 207 embryos that were initially subjected to the procedure, the success rate for the creation of gastroschisis was $8.7 \%$ (95\% CI: 5.4 to 13.6$)$.

Of the 17 embryos of the mixture group (M), 12 $(70.5 \%)$ survived the experiment. Therefore, the survival rate of the embryos in the mixture group was $70.5 \%$.

Comparatively, the survival of the gastroschisis group was $11.1 \%$ and of the mixture group was $70.5 \%$, there was a statistically significant difference between them $(p=0.045)$.

The comparison of the embryo weight and the embryo/egg weight ratio in the three groups showed a statistically significant difference, demonstrating that there was some weight loss in the embryo of the gastroschisis group when compared with the mixture and control groups.

The assessment by inspection of the exposed viscera at birth showed that, in all cases in the gastroschisis group, the exposed viscera consisted of loops of the small intestine. In none of the cases was an exposed liver observed. In the groups $\mathrm{M}$ and $\mathrm{C}$, the umbilical cord was found to be intact upon the opening of the egg, and no case presented exposed viscera.

The microscopic evaluation of the intestinal loops based on the previously described score ${ }^{9}$ classified the serositis, enteritis, fibrin and collagen formation and necrosis findings. The groups $\mathrm{M}$ and $\mathrm{C}$ showed just a few changes at the histopathological examination. Different injury degrees could be observed in the group G (Figure 2).

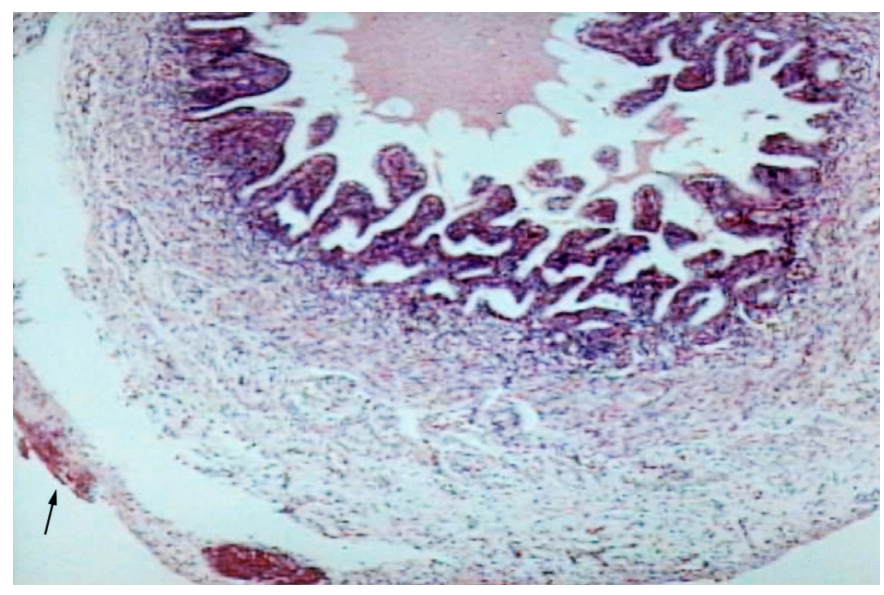

FIGURE 2 - Histological section of the exposed intestine from an embryo in the Group G (100X). Observe the thickening of the wall, edema, and inflammatory infiltrate in the serosa

The comparison of the scores obtained by the three groups showed a statistically significant difference for all parameters (serositis, enteritis, necrosis, fibrin and collagen formation and total) of the group $\mathrm{G}$ in relation to the other two groups (Table 1).

TABLE 1 - Histological analysis of the small intestine loops of the three groups based on a standardized score ${ }^{9}$ (mean + standard deviation)

\begin{tabular}{|c|c|c|c|c|}
\hline \multirow{3}{*}{ Findings } & \multicolumn{3}{|c|}{ Groups } & \multirow{3}{*}{$\mathbf{P}$} \\
\hline & G & M & C & \\
\hline & $n=18$ & $n=12$ & $n=10$ & \\
\hline Serositis & $2.17 \pm 0.79^{a}$ & $0.25 \pm 0.45^{b}$ & $0.3 \pm 0.48^{b}$ & $<0.001$ \\
\hline Enteritis & $1.83 \pm 1.04^{\mathrm{a}}$ & $0.25 \pm 0.45^{b}$ & $0.3 \pm 0.67^{b}$ & $<0.001$ \\
\hline Necrosis & $0.94 \pm 1^{a}$ & $0^{b}$ & $0^{b}$ & $<0.001$ \\
\hline $\begin{array}{l}\text { Collagen and } \\
\text { fibrin }\end{array}$ & $1.28 \pm 1.07^{\mathrm{a}}$ & $0^{b}$ & $0^{b}$ & $<0.001$ \\
\hline Total & $6.22 \pm 3^{a}$ & $0.5 \pm 0.8^{b}$ & $0.6 \pm 0.84^{b}$ & $<0.001$ \\
\hline
\end{tabular}

The non-coincident letters indicate statistically significant differences. 
There was no statistically significant difference in the count of nerve plexuses in the three groups under study.

The values of intestinal thickness showed a statistically significant difference in the serosa and mucosa measurements. The thickness of the muscular layer did not present any difference.

A difference was found in total thickness between groups $\mathrm{G}$ and $\mathrm{C}$; however, this difference (which may be con- sidered as being of a moderate size) did not attain a classical statistical significance. Nevertheless, when a linear regression analysis was conducted, since the groups were sorted by magnitude of effect, a borderline significance was found $(\mathrm{p}=0.056)$. This means that the greater the exposure of the embryo to the modified amniotic fluid, the greater the thickness observed in the intestinal wall (Table 2).

TABLE 2 - Intestinal thickness measures in micrometers

\begin{tabular}{|c|c|c|c|c|}
\hline \multirow[b]{2}{*}{ Layers } & \multicolumn{3}{|c|}{ Groups } & \multirow[b]{2}{*}{$\mathbf{P}$} \\
\hline & G & $\mathbf{M}$ & C & \\
\hline & $n=18$ & $n=12$ & $n=10$ & \\
\hline Mucosa & $187.13 \pm 16.45^{a}$ & $175.31 \pm 12.77^{b}$ & $176.85 \pm 7.71^{a, b}$ & 0.048 \\
\hline Muscular & $173.76 \pm 71.98$ & $194.73 \pm 57.97$ & $181.68 \pm 52.87$ & 0.679 \\
\hline Serosa & $96.98 \pm 25.57^{a}$ & $62.41 \pm 14.26^{b}$ & $51.7 \pm 10.76^{c}$ & 0.001 \\
\hline Total & $457.86 \pm 75.34$ & $432.46 \pm 54.27$ & $410.24 \pm 45.64$ & 0.163 \\
\hline
\end{tabular}

The non-coincident letters indicate statistically significant differences.

\section{Discussion}

Chicken embryo is a unique model, especially because the procedure cannot be carried out in the period in which the intestine protrudes through the hernia of the umbilical cord and for the reason that the amniotic fluid is free of fetal urinary and intestinal rejects, which are contained in the allantoic sac. Thus, one can choose to create a gastroschisis by mixing or not cloacal rejects of the embryo with the amniotic fluid, this will pretty much depend on the stage of embryonic development in which the procedure is carried out. Creating a gastroschisis bathed only by the amniotic fluid, without dejects, may be useful when one wants to separately test substances that are irritant to the intestine, such as human urine and meconium.

Undoubtedly its main advantages are the low cost of the experiment, easy disposal, no need for anesthesia, and the use of just a few surgical materials.

Another advantage is that, in the chicken embryo, gastroschisis can be carried out in the early developmental stages, when embryogenesis is believed to take place ${ }^{7,8}$.

The costs with this experimental model are pronouncedly lower than with other animals, embryonated chicken eggs cost extremely low, and the expenses on incubation and surgical procedure are modest as well.

The main disadvantages of the chicken embryo as an experimental model comprise the high mortality rate, the differences observed in the embryonic membranes, and the differences in the composition of the amniotic fluid.
One of the critiques of the chicken model is that the composition of the amniotic fluid and of the animal's blood is different from that of the mammals, especially man. The plasma and amnioallantoic fluid osmolarity of the chicken embryo is actually lower than in humans ${ }^{7}$; however, the behavior of the amnioallantoic fluid and the human amniotic fluid is similar. Both present a decrease in sodium levels, elevation in the concentration of potassium, urea and creatinine, related to the beginning of full renal functioning, which takes places around the $15^{\text {th }}$ day in chicken embryos and in the $30^{\text {th }}$ week in human fetuses ${ }^{8}$.

The choice of the best moment to create gastroschisis in chicken embryos takes into account several factors. As this experiment was intended to create conditions for the amniotic fluid that were similar to those of the human amniotic fluid, the procedure should be carried out after the $7^{\text {th }}$ day of development ${ }^{7}$. However, 7-day old embryos are small animals and are hard to manipulate without microscopes or surgical loupes.

The choice of performing the procedure on the $13^{\text {th }}$ day was based on a majority of articles that considered optimal to perform it around this day ${ }^{7,8}$; likewise, the final procedure was carried out on the $19^{\text {th }}$ day to provide a relatively long period of exposure of the intestinal loops to the amnioallantoic fluid and because on the $20^{\text {th }}$ and $21^{\text {st }}$ days the embryo grows significantly, starts to intensively move within the egg, the amount of fluid decreases, and there is risk of adherence of the 
eviscerated intestine to other structures. However, some authors ${ }^{7,8}$ have demonstrated that the earlier in the embryonic development a gastroschisis is created, the longer its survival.

The survival based on this study is considered low even in comparison with other studies with chicken embryos.

The development of the hook for manipulating and pulling the umbilical cord was crucial to prevent damage to the embryo. With the hook, it is possible to open the membranes in a blunt fashion and with little bleeding; also, the pull on the umbilical vessels became thereby safer. There are no reports in the literature researched on its use.

Another important aspect to be discussed is the fact that in experimental murine and rabbit models an evisceration through the defect ${ }^{10,11}$ of the liver, stomach, large intestine, bladder and even kidneys is often observed, while in the chicken embryo there is evisceration of the large intestine only, which seems to mirror better what occurs in most patients with gastroschisis.

The fact that the embryo weight was lower in the group $\mathrm{G}$ than in the groups $\mathrm{M}$ and $\mathrm{C}$ demonstrated that the exposure of intestinal loops in the experimental model promoted a low weight, which is a common characteristic of gastroschisis ${ }^{12}$.

Similarly, the embryo/egg weight ratio (EE) was lower in the gastroschisis group. The control of the embryo/egg weight ratio is useful to reduce potential variations in egg weight.

The histological analysis performed by means of the standardized score showed that the group $\mathrm{G}$ was distinctive in relation to all the aspects assessed in the groups $\mathrm{M}$ and $\mathrm{C}$. Undoubtedly, the exposure of the intestine to the amnioallantoic fluid was the cause of this difference. In all studies in chicken embryos used as models for gastroschisis, changes such as serositis, enteritis, necrosis and collagen and fibrin formation are observed at different degrees ${ }^{7,8}$.

The serosa was shown to be the location where greater changes occurred, this certainly arises from the fact that the serosa is the surface that is in actual contact with the amnioallantoic fluid. Also, in the study of human fetuses conducted by Amoury et al. ${ }^{13}$, it was the serosa that showed a greater compromise, demonstrating edema and accumulation of collagen and fibrin. In the sheep models of Haller et al. ${ }^{14}$, a major hypertrophy of the visceral peritoneum took place. Subserous edema and collagen and fibrin formation seem to be consistent findings in humans and chicken embryos ${ }^{13}$. Langer et $a l .{ }^{15}$ described an intensive inflammatory reaction with granulation tissue and neovascularization in the serosa of their sheep model, which was found in the present study as well.

Compared with rabbit fetus models, the chicken embryo is able to reproduce the findings of collagen and fibrin formation, which are not demonstrated in the experiments with rabbits $^{16}$. Since collagen and fibrin formation is considered an important element in the characterization of the gastroschisis intestine, being also associated with intestinal motility disor$\operatorname{ders}^{15}$, rabbit models fail in this respect. The time of intestinal exposure to the amniotic fluid is not likely to be sufficient to develop a fibrin and collagen layer in rabbits.

Ischemic changes were observed in the specimens of group $\mathrm{G}$, consisting of necrosis in the mucosa and areas of parietal necrosis. These changes that are not observed in other mod- els ${ }^{14}$ have already been described by TibboeL et al. ${ }^{6}$ and AKTUG et al. ${ }^{8}$.

The simple count of the number of myoenteric nerve plexuses did not show any difference in the three groups in this study. This also occurs in the series of gastroschisis in humans of Amoury et al..$^{13}$. However, Haller et al. ${ }^{14}$, in their sheep model, were able to demonstrate injury in the myenteric ganglionic cells and progressive decrease in the activity of the ATPase in the muscular layers of the intestinal wall, accounting thus for the peristaltic changes. Recently, Santos ${ }^{16}$ made a deeper analysis of the myoenteric plexuses in a rabbit gastroschisis model using special histochemical techniques and identified a clear deficiency in the neuronal maturation of the intestine.

The thickening of the intestinal wall is ascribed to enzymes originated from the gastrointestinal tract of the embryo, such as phosphatase alkaline, disaccharidases and trypsin, dissolved in the fluid in contact with the loops ${ }^{17}$. Interestingly, these substances are present in the amniotic fluid of normal human pregnancies, yet absent when the fetus presents intestinal atresia or cystic fibrosis. The presence of biliary salts and bilirubin in the mixtures of fluids ${ }^{8}$ was also demonstrated in chicken embryos.

Which one of these substances is directly involved in the findings or to what extent each one of them plays any role are questions that need further studies to be answered.

\section{Conclusion}

The experimental gastroschisis model with chicken embryos can be reproduced under the conditions established in this study. The histological changes observed are comparable to those of human gastroschisis and were not present in the intestine unexposed to the amnioallantoic fluid.

\section{References}

1. Earlam RJ. A study of the aetiology of congenital stenosis of the gut. Ann Roy Coll Surg Engl. 1972;51:126-30.

2. Kleckner SC, Pringle KC, Clark EB. The effect of chick embryo hyperflexion on tracheoesophageal development. Pediatr Surg. 1984;19(4):340-4.

3. Meijers JH, Tibboel D, van der Kamp AW, van HaperenHeuts IC, Molenaar JC. A model for aganglionosis in the chicken embryo. J Pediatr Surg. 1989;24(6):557-61.

4. Tibboel D, van der Kamp AW, Molenaar JC. The effect of experimentally induced intestinal perforation at an early developmental stage. J Pediatr Surg. 1981;16(6):1017-20.

5. Olguner M, Akgur FM, Ozdemir T, Aktug T, Ozer E. Amniotic fluid exchange for the prevention of neural tissue damage in myelomeningocele: an alternative minimally invasive method to open in utero surgery. Pediatr Neurosurg. 2000;33(5):252-6. 6. Tibboel D, Molenaar JC, Van Nie CJ. New perspectives in fetal surgery: the chicken embryo. J Pediatr Surg. 1979;14(4):438-50.

7. Lopez de Torre B, Tovar J, Uriarte S, Aldazabal P. Transperitoneal exchanges of water and solutes in the fetus with gastroschisis: experimental study in the chick embryo. Eur J Pediatr Surg. 1991;1 346-52. 
8. Aktug T, Uçan B, Olguner M, Akgür F, Özer E: Amnio-Allantoic fluid exchange for prevention of intestinal damage in gastroschisis II: effects of exchange performed by using two different solutions. Eur J Pediatr Surg. 1988;8:308-11.

9. Ferreira PR, Motta UIC, Ferreira M, Bica CG, Zetler CG. Alterações microscópicas no intestino do rato causadas pelo mecônio e pela urina. Rev Pesq Med. 2000;34(2):71-6.

10. Aoki Y, Ohshio T, Komi N. An experimental study on gastroschisis using fetal surgery. J Pediatr Surg. 1980;15(3):2526.

11. Phillips D, Kelly Jr, RE, Fonkalsrud EW, Mirzayan A, Kim AS. An improved model of experimental gastroschisis in fetal rabbits. J Pediatr Surg. 1991;26(7):784-7.

12. Moore T, Nur K. An international survey of gastroschisis and onphalocele (409 cases). Pediatr Surg Int. 1986;1:105-9. 13. Amoury RA, Beatty EC, Wood WG, Holder TM, Ascheraft KW, Sharp RJ, Murphy JP. Histology of the intestine in human gastroschisis - relationship to intestinal malfunction: dissolu- tion of the "peel" and its ultrastructural characterirstics. J Pediatr Surg. 1988;23(10):950-6.

14. Haller JA Jr, Kehrer BH, Shaker IJ, Shermeta DW, Wyllie RG. Studies of the pathophysiology of gastroschisis in fetal sheep. J Pediatr Surg. 1974;9(5):627-32.

15. Langer JC, Longaker MT, Crombleholme TM, Bond SJ, Finkbeiner WE, Rudolph CA, Verrier ED, Harrison MR. Etiology of intestinal damage in gastroschisis. I. Effects of amniotic fluid exposure and bowel constriction infetal lamb model. J Pediatr Surg. 1989;24(10):992-7.

16. Santos, MM. Alterações na maturação dos plexos nervosos entéricos na gastrosquise: Estudo experimental (Tese de Doutorado). Faculdade de Medicina da Universidade de São Paulo; 2000.

17. Morin PR, Potier M, Dallaire L, Melançon SB, Milunsky A. Prenatal detection of intestinal obstruction: deficient amniotic fluid disaccharidases in affected fetuses. Clin Genet. 1980;18:217-22.

\section{Correspondence:}

Conflict of interest: none

Carlos André Tarrio Gandara

Financial source: none

Rua Marechal Floriano, 555/sala 803

9502-0370 Caxias do Sul-RS Brazil

gandara@terra.com.br

Received: November 12, 2007

Review: January 15, 2008

Accepted: February 14, 2008

\section{How to cite this article}

Gandara CAT, Araújo ES, Motta UIC. Chicken embryo as an experimental model for the study of gastroschisis. Acta Cir Bras. [serial on the Internet] 2008 May-June;23(3). Available from URL: http://www.scielo.br/acb

*Color figures available from www.scielo.br/acb 